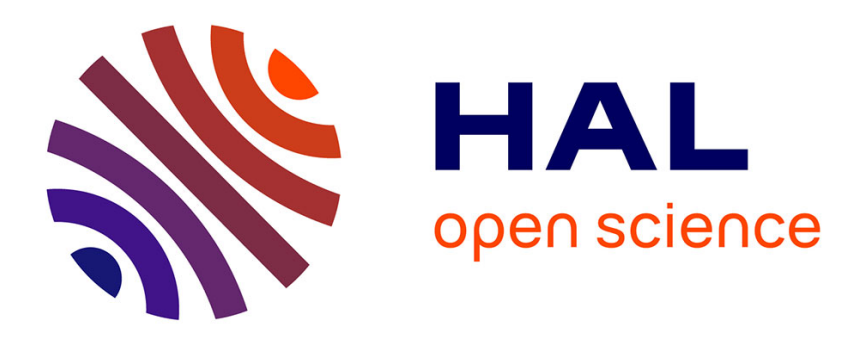

\title{
A French story of the ESR dating method for Quaternary samples
}

Christophe Falguères

\section{To cite this version:}

Christophe Falguères. A French story of the ESR dating method for Quaternary samples. Quaternary International, 2019. hal-03013893

\section{HAL Id: hal-03013893 \\ https://cnrs.hal.science/hal-03013893}

Submitted on 19 Nov 2020

HAL is a multi-disciplinary open access archive for the deposit and dissemination of scientific research documents, whether they are published or not. The documents may come from teaching and research institutions in France or abroad, or from public or private research centers.
L'archive ouverte pluridisciplinaire HAL, est destinée au dépôt et à la diffusion de documents scientifiques de niveau recherche, publiés ou non, émanant des établissements d'enseignement et de recherche français ou étrangers, des laboratoires publics ou privés. 
A French story of the ESR dating method for Quaternary samples

Christophe Falguères

Département Homme et Environnement, Muséum national d'histoire naturelle, UMR7194, Sorbonne Université, Institut de Paléontologie Humaine, Paris, 75013, France

\begin{abstract}
This is the story of the ESR team at Muséum national d'histoire naturelle of Paris, which has been involved in Quaternary dating for 40 years. It is a dedication to Yuji Yokoyama who created this laboratory and contributed to its development. The history of the ESR dating laboratory is presented since its beginnings in the CFR lab at Gif-sur-Yvette to its current location at the Muséum.
\end{abstract}

\title{
Key-words
}

ESR; Yuji Yokoyama; calcite; quartz; enamel

\section{Introduction}

Electron Spin Resonance as a dating method (ESR) was introduced by Motoji Ikeya who published the first paper on ESR dating of a calcite sample from Akiyoshi cave in Japan (Ikeya, 1975). This novel application was picked up by another Japanese researcher, Yuji Yokoyama, who was in France for working on lunar samples. He decided to implement the ESR method at the "Centre des Faibles Radioactivités" (CFR) at Gif-sur-Yvette. Jacques Labeyrie, at the head of the CFR, favoured the development of radiometric methods to date events related to past climates. At the time, CFR researchers developed thermoluminescence dating (Georges Valladas), U-series dating (Claude Lalou), and radiocarbon (Georgette Delibrias). The CFR dating laboratories drew the attention of many prehistorians including Henry de Lumley, Professor at the Museum of Paris, who understood the importance of the dating methods for prehistory. Yuji Yokoyama was an eminent specialist in nuclear physics with a particular interest in cosmic rays. He simultaneously developed ESR and gamma-ray spectrometry and set up a pioneering laboratory for U-series dating of human remains based on the non destructive gamma-ray spectrometry (Yokoyama et Nguyen, 1980; 1981a). He formed an ESR team that began to work on fundamental studies on calcite and notably on the nature and stability of trapped electrons in this mineral. Then he moved to the Muséum national d'histoire naturelle where he founded a new dating laboratory with his students. For the first time in France, a dating laboratory was settled in a research environment dedicated to prehistory. 


\section{In the beginning was.... Arago cave!}

The first prehistoric site involved in this story is Arago cave in southern France, excavated by Prof H. de Lumley and where more than 150 human remains have thus far been unearthed in association with hundreds of thousands of faunal and lithic artefacts along a ten meters thick sequence. Among them, the famous Arago XXI skull is the first human fossil to be dated by non-destructive gamma-ray spectrometry (Yokoyama and NGuyen, 1981a; 1981b). An age of $455+\infty /-210$ ka was obtained. In spite of heavy criticism at the time of the publication (see de Lumley and Labeyrie, 1981), this pioneering result has been reconfirmed by new dates obtained by U-series on calcite, ESR on quartz, and ESR/U-series on teeth (Falguères et al., 2004, 2015). In 1981, an international colloquium on Absolute dating and isotope analysis in prehistory was organized to discuss the chronology of the site. More than 250 samples were collected and distributed to about 20 international laboratories using a variety of methods including U-series, thermoluminescence, fission tracks, amino acid racemization, and electron spin resonance (see papers in Lumley de and Labeyrie, 1981). The large spread of the results was perplexing and obscured the true age of the site triggering hotly debated discussions (Figure 1). This first Colloquium, however, made both physicists and prehistorians aware of the difficulties in accurately dating a prehistoric site.

The ESR results presented at the colloquium were carried out on bones, calcite and quartz. The ESR section in the proceedings is opened by a review of M. Ikeya (1981) based on the previously published articles (Ikeya, 1975; 1978). The ESR dating paper by Yokoyama et al. (1981a) addressed some of the main problems such as uranium concentration variations, U-series disequilibrium (escape of radium and radon), water content and alpha/beta effectiveness, k-value, for which an analytical device was built according the description of Zimmerman (1971). Several values ranging between 0 and 1 were measured for $\mathrm{k}$ for three bones. Yokoyama et al. (1981a) experimentally determined a k-value of 0.084 for the bones from Arago. Grün and Katzenberger (1994) measured later a $\mathrm{k}$ value of $0.13 \pm 0.02$ for enamel sample. At this time, the dose values, $\mathrm{D}_{\mathrm{E}}$, were calculated using a linear extrapolation with 5-6 data points and the obtained values varied from sample to sample by a factor of 10 implying a wide spread in the ages of the human bearing layers. Moreover, Unit G, the layer richest in human remains, is in places severely weathered by phosphates and bat guano. The bones from Unit $\mathrm{G}$ yielded ESR ages of between 145 and $285 \mathrm{ka}$, generally too young! These studies demonstrated the difficulties in ESR dating of bones. This subsequently led geochronologists to direct their research towards fossil tooth enamel, which seems intrinsically better suited for ESR dating than bones (see Grün and Schwarcz 1987) and for which the U-uptake history can be experimentally determined (Grün et al., 1988). 
Preliminary results were presented on ESR dating on calcite samples coming from the base of the sequence (Ensemble I) and from Ensemble IV of Arago cave (Yokoyama et al., 1981b; 1982). The ESR spectra of calcite show several lines (see Ikeya, 1993). Most authors recommend the use of the signal at $\mathrm{g}=2.0007, \mathrm{~h}_{3}$, either for corals, mollusk shells, speleothems or travertines (see Grün, 1989; Rink, 1997). The lifetime of the line at $\mathrm{g}=2.0007$, determined by the Arrhenius law, is short in speleothems and varies according to authors from $210^{5}$ years (Yokoyama et al., 1983) to $610^{7}$ years (Smith et al., 1985). Grün (1989) considered it to be a few million years range. The association of the $\mathrm{CO}_{2}^{-}$radical, responsible for $\mathrm{h}_{3}$, with water molecules within the crystal could skew the experimental determination of the thermal stability, which uses thermal annealing (Debuyst et al., 1993). Other processes such as recrystallization of carbonates may also have influence on the thermal stability (Barabas et al., 1992). Isochron annealing experiments suggested that the signal at $\mathrm{g}=2.0057$ is the most stable observed in Quaternary natural carbonates (Bahain et al., 1994) despite the controversy caused by the fact that this signal was not sensitive to gamma radiation. Figure 2 shows that $h_{1}$ signal intensity increases when the sample is irradiated with a gamma dose of $47 \mathrm{krad}(470 \mathrm{~Gy})$ after pre-annealing for $16 \mathrm{~h}$ at $190^{\circ} \mathrm{C}$ (Figure 2A). Figure 2B shows an increase of $h_{1}$ line while $h_{3}$ signal decreases as a function of annealing time at elevated temperatures. This phenomenon may correspond to a spontaneous transfer of electrons from $h_{3}$ to $h_{1}$ which would also occur at ambient storage temperatures during the geological history of the sample (Yokoyama et al., 1981b; 1983).The decrease of $h_{3}$ is therefore not only due to the release of the trapped electrons, as a result of temperature (thermal release), but also to the destruction of the trap itself (trapdecay), which does not occur during geological time (Barabas et al., 1992b ; Walther et al., 1992). A comparative study was performed on a thick stalagmitic floor and dated using several ESR signals (Bahain et al., 1994). The first results implied that the $h_{3}$ results were too young, suggesting a short life-time of $h_{3}$ line. However, several authors consider that the use of $h_{1}$ signal after thermal annealing experiments leads to age overestimations (Hennig and Grün, 1983; Skinner, 1983; Grün, 1989). Presently, the discussion is not over but the development of mass spectrometric U-series dating is used on carbonates and allows the determination of ages of up to 600 ka with an excellent precision (Edwards et al., 1987; Potter et al., 2005). A recent article on Basura stalagmitic floor yielded U-series age confirming the antiquity of the calcite of more than $530 \mathrm{ka}$ (Pozzi et al., 2019). Some studies were performed on quartz grains at room temperature (Quaegebeur and Yokoyama, 1981). ESR spectra showed sharp lines and broad absorption band which could correspond to E' and peroxy centers. No dating procedure was made. 


\section{Sea, quartz and sun!}

ESR dating of quartz began in the late sixties with three papers of McMorris (1969; 1970; 1971) introducing the possibilities of using this ubiquitous mineral. Physicists had already published several important studies on ESR applications on quartz and silicas (Mackey et al., 1970; Griscom, 1978; Poole et al., 1978; Marfunin, 1979; Weil, 1984). One of the first papers on ESR dating of bleached quartz was published by our team (Yokoyama et al., 1985), and we have not stopped working on this mineral since. Beach and wind-blow sands from the Terra Amata and Arago sites were tentatively dated by ESR using the aluminium center in quartz grains measured at low temperatures $\left(93^{\circ} \mathrm{K}\right)$. A comparison of the dose response curves of each hyperfine lines of $\mathrm{Al}$ center is made and leads to the $\mathrm{D}_{\mathrm{E}}$ by measuring the signal intensity peak to peak height between the top of line \#1 $(\mathrm{g}=$ $2.0185)$ to the bottom of line \#16 ( $\mathrm{g}=1.9928)$. This method was confirmed by Toyoda and Falguères $(2003)$. It avoids a potential interference by the peroxy signal (Odom and Rink, 1989). A second important point is the observation of saturation effects in the aluminium dose response curves, which are well fitted by an exponential equation as already suggested for other types of samples (Apers et al., 1981; Ikeya, 1981). The residual signal, corresponding to an incomplete bleaching of the aluminium center, is extracted from modern-analogue samples such as present beach sands and surface alluvial soils, and is subtracted from the natural ESR intensity allowing the determination of the $\mathrm{D}_{\mathrm{E}}$ value. The first UV bleaching experiments were conducted on Arago samples but the $4 \mathrm{~W}$ black UV lamp used was apparently too weak for emptying the traps and the experimentally determined residual level was $80 \%$ of the natural intensity. In spite of large errors accompanying these preliminary ages, the results were consistent with other data obtained on both sites (Lumley H. de, 1967; Lumley H. de and Lumley M. A. de, 1971).

When working on quartz, the first idea was to look at burnt sediments in order to minimize the problem of the residual signal. A preliminary study was performed on sediments baked by lava-flows and comparing for the first time the $\mathrm{D}_{\mathrm{E}}$ obtained by $\mathrm{Al}$ and Ti centers (Yokoyama et al., 1986). For the Ti center, three components are identified in accordance with the literature (McMorris, 1971) but the measurement of the signal intensity was made without dissociating Ti-Li, Ti-H and Ti-Na, leading to conclusions on thermal annealing of this complex center that have been reconsidered since (Toyoda, 1992; Voinchet et al. 2007; Duval and Guilarte, 2014). The burnt sediments were provided by the "Laboratoire de Physique corpusculaire" of Clermont-Ferrand, which had measured the TL on quartz, marking the beginning of a fruitful collaboration with D. Miallier and his team. 
Preliminary analyses were performed on the same type of burnt quartz but it was not possible to correlate the ESR signals ( $\mathrm{Al}$ and $\mathrm{Ti}$ centers) and TL peaks (RTL around $600-620 \mathrm{~nm}$ at $380^{\circ} \mathrm{C}$ ) probably because of the sensitivity difference between the methods (Falguères et al., 1991; Miallier et al., 1994). Later, measurements were performed on detrital marine, aeolian sands, and on volcanic and baked sediments. In some samples, the presence of the E' center (Feigl et al., 1974) was observed at room temperature (Falguères et al., 1994). Based on laboratory annealing experiments, it seems possible to use E' center for evaluating the effective temperature at which the samples heated to by the contact with volcanic materials (Figure 3).

An optical bleaching device was built to understand the bleaching characteristics of the aluminium center in natural sedimentary quartz. A bleaching curve of quartz from fossil sediment shows that the maximum bleaching for $\mathrm{Al}$ center is about $52 \%$ after around $820 \mathrm{~h}$ of laboratory light exposure (halogen and UV lamps) equivalent to 6 months of sun light (Figure 4) (Voinchet et al., 2003; 2007). This process to evaluate the maximum bleaching level has been criticized by some OSL users (Stokes, public comment, 2002). However, today thermally transferred optically stimulated Luminescence (TT-OSL) utilizes deep traps for dating the Early Pleistocene period (Arnold et al., 2015). These TT-OSL signals in single grains show also relatively slow optical characteristics (Arnold et al., 2019).

The sun light bleaching responses of the $\mathrm{Al}$ and $\mathrm{Ti}$ centers were studied in collaboration with Prof S. Toyoda with whom we share an interest in ESR dating on quartz and particularly in sun light bleaching characteristics and the sensitivity of Ti centers (Ti-Na, Ti-H, Ti-Li, Toyoda et al., 2000). This paper established the basis of the Multiple Centre Approach which represents a major breakthrough in ESR Dating of quartz. A JSPS grant was obtained by our colleague $\mathrm{H}$. Tissoux who spent 2 years in Toyoda's lab working on the potential of $\mathrm{Al}$ and Ti centers for dating sediments (Tissoux et al., 2007; Tissoux et al., 2008).

Even if the bleaching mechanism is not yet completely understood, it has opened the door for ESR dating of a number of open air prehistoric sites associated with fluvial deposits located in the northern part of Europe (Despriée et al., 2018; Voinchet et al., 2010; 2015; Moncel et al., 2013), Spain (Duval et al., 2015; Moreno et al., 2012; Toro-Moyano et al., 2013), Southeast Asia (Ingicco et al., 2018) and China (Voinchet et al., 2019). Presently, when old sites are not located in volcanic areas, ESR applied on optically bleached quartz and, thanks to the great stability of Al center (Toyoda and Ikeya, 1991), is the only method able to provide ages as far as 2.4 Ma (Sahnouni et al., 2018).

\section{Modeling the uranium uptake in fossil enamel}

After the first tentative attempts of ESR dating of hydroxyapatite (Ikeya, 1978), ESR dating was applied to 
bones but the results were not satisfying, as mentioned previously, due to the frequent heterogenous distribution of uranium and "the great complexity of the diagenetic processes" in bones (Grün and Schwarcz, 1986). At the end of the eighties, an important paper provided an equation allowing the determination of the uranium uptake parameter in fossil enamel with the restriction that the sample should not undergo any uranium leaching (Grün et al., 1988). To solve for the uranium uptake parameter, $p$, it is necessary to measure U-series ages on the dental tissues that contribute to the dose in the enamel, i.e. the enamel itself, as well as adhering dentine and, if present, cement. The p-value is derived from the combination of the ESR and U-series age equations (US-ESR model). Mammalian teeth and particularly thick herbivorous enamel are suitable for obtaining reliable results. Y. Yokoyama wrote a program allowing the age calculation of several prehistoric sites using the p-value system well before the publication of the program written by Grün (2009).

A comparative approach was performed on teeth from Isernia dated by ESR and minerals by K-Ar method (Bahain et al., 1992). The US-ESR model using a hypothesis of inverse correlation between ESR signal height and uranium concentration resulted in an age of about $450 \mathrm{ka}$, far from the first $736 \mathrm{~K}$-Ar age (Coltorti et al., 1982) which was later adjusted by ${ }^{40} \mathrm{Ar} /{ }^{39} \mathrm{Ar}$ measurements to $610 \mathrm{ka}$ (Coltorti et al., 2005), and recently to 583$561 \mathrm{ka}$ on sanidine crystals (Peretto et al., 2015). The heterogeneous uranium distribution observed in the elephant tooth enamel was a reason explaining the age difference between the ESR and K-Ar methods. Due to their lamellar structure they may favour uranium migration which is strongly correlated with the fossilization processes (Grün and Invernati, 1985). The authors conclude that "it is necessary to develop a model of Uuptake for each bone and tooth". Large proboscidian teeth were subsequently not used for ESR dating, at least by the French team. We suspected that the ESR age underestimation was due to the variations in the external gamma-dose rate. The archaeological layer contains a very large number of bones and these may have accumulated uranium in recent times. Such a process results in a much higher gamma dose rate today than it was in the past (Shao et al., 2011). In Figure 5, time-integrated gamma doses are calculated using the Ar-Ar age as a reference, and assuming that a massive uranium uptake occurred during an interglacial period. The results suggest that this event occurred during MIS7 and not during MIS5 as proposed previously (Falguères et al., 2007). While ESR dating has provided reliable results for Middle Pleistocene sites (Bahain et al., 2015; Falguères et al., 2010; Pereira et al., 2017), it is more difficult to obtain reproducible results for sites older than 800 ka. Except for the Gran Dolina sequence, for which a multi-methods approach yielded ages ranging between 800 and 900 ka for TD6 layer containing Homo antecessor (Perez-Gonzalez and Pares, 1995; Falguères et al., 1999; Moreno et al., 2015; Arnold et al., 2016; Berger et al., 2008), combined ESR/U-series applied to various Lower Pleistocene prehistoric sites highlighted the difficulties for establishing chronologies for this period. A study of 20 teeth from different Spanish sites showed a general trend of age underestimation 
probably in relation with their geological context and their state of conservation (Duval et al., 2012). A 3-D LA ICPMS MC investigation on a horse tooth (Figure 6) demonstrated that this type of analysis allows the evaluation of the most appropriate areas of dental tissues to be dated avoiding the altered zones presenting heterogeneous uranium distributions (Duval et al., 2011). Several studies have recently been published on dating the final Middle Palaeolithic cultures by ESR/U-series (Richard et al., 2015; Ben Arous et al., 2019). Paradoxically, for such an important period in human evolution, marked by the disappearance of Neanderthals, it is difficult to obtain a well resolved chronologies, because radiocarbon is limited to samples younger than 40$45 \mathrm{ka}$, whereas luminescence and ESR ages are associated with relatively large errors on this period range. Several constraints such as a clear identification of the transitional layers in sites, heterogeneity of sedimentary deposits increased by the difficulties for getting accurate isotopic ratios and $U$ concentration in tissues, render problematic the production of accurate results allowing a firm attribution of the archaeological layers to Homo sapiens or Neanderthals (Higham et al., 2014).

\section{Conclusion}

This contribution, which presents some of the results obtained during the 40 years of the life of the Parisian ESR team is a tribute to Yuji Yokoyama (1926-2015) who had introduced ESR as a dating method in France opening the gate for a generation of researchers. He contributed greatly to include dating methods as an essential tool in any multidisciplinary approach in prehistorical studies. Table 1 refers the great major part of the work performed by his team using ESR and U-series methods, with a list of publications and PhD defences in Supplement Information. He had a vision for the place of the geochronology in prehistory but he was also fully aware of the problems that are involved in obtaining reliable ages. He was one of the first to make in situ measurements of the external dose rate and to perform analyses on the alpha/beta effectiveness. I would like to thank him on behalf of all his students for having given us the taste of scientific curiosity and analytical precision, not such an easy task! His name is inseparable from the development of ESR dating in France. 


\section{Acknowledgements}

I would like to thank the three reviewers who have contributed to improve this paper. Since 1980, we have collaborated with many prehistorians, the list would be too long to be reproduced here, but I want to thank them all warmly for giving access to their sites. I thank also Jean-Pierre Quaegebeur, Concèle Léger and Roland Bibron from CEA, France, who were the first of Yokoyama's collaborators to begin this paramagnetic adventure. Georges Valladas taught to me how to prepare quartz grains in his great simplicity! I think often to him. I am particularly grateful to Jacques Labeyrie and Henry de Lumley accepting me in their lab. We have been working with Jackie Despriée for more than 25 years and he is the collaborator that everyone wants to have. Thank you Jackie! Jean Michel Dolo helped us for the questions of artificial irradiations and became a good friend also. Of course, all my thanks go to Yuji Yokoyama who gave a lot to ESR in general and to our team in particular! I do not forget Jean-Jacques Bahain and Pierre Voinchet, the pillars of our team who contribute daily to the development of our lab and the training of many students. I have a special thought for Jean and for Louis. 


\section{Figure caption}

Figure 1: ESR and U-series dating on bones (red and grey squares) and on calcite (red and grey circles) showing a very large spread of the ages for the human bearing occupation layers. These analyses were performed by several labs and presented at the colloquium of Tautavel in 1981 (modified from Falguères et al., 2004).

Figure 2: A) ESR spectra of Arago stalagmitic calcite YC62. (a) natural spectrum, (b) natural + artificial gamma-ray of $47 \mathrm{krad}$, (c) natural spectrum after pre-annealing at $190^{\circ} \mathrm{C}$ for $16 \mathrm{~h}$, (d) natural + artificial gamma-ray of $47 \mathrm{krad}$ after pre-annealing at $190^{\circ} \mathrm{C}$ for $16 \mathrm{~h}$. B) Decrease of the $\mathrm{h}_{3}$ and increase of the $\mathrm{h}_{1}$ line as a function of annealing time at an annealing temperature of $200.5^{\circ} \mathrm{C}$ (after Yokoyama et al., 1983).

Figure 3: ESR spectra of non irradiated samples: a) sand dune showing OHC and E' centers; b) pumice in which no center is observed. $\mathrm{P}=2 \mathrm{~mW}$; modulation $=1.25 \mathrm{G}$, cavity temperature $=300^{\circ} \mathrm{K}$ (modified from Falguères et al., 1994).

Figure 4: Bleaching curve of quartz extracted from a fossil sediment. For each point, uncertainty of ESR

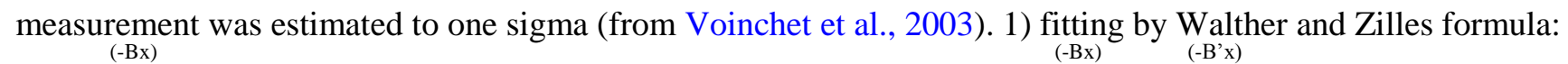
$\mathrm{y}=\mathrm{Ae}{ }^{(-\mathrm{Bx})}+\mathrm{C}$ (Walther and Zilles, 1993) 2) fitting by the equation: $\mathrm{y}=\mathrm{Ae}{ }^{(-\mathrm{Bx})}+\mathrm{A}^{\prime} \mathrm{e}^{\left(-\mathrm{B}^{\prime} \mathrm{x}\right)}+\mathrm{C}$ (Voinchet et al., 2003)

Figure 5: Comparison of combined ESR/U-series dates with that obtained by ${ }^{40} \mathrm{Ar} /{ }^{39} \mathrm{Ar}$ age of the Pleistocene site of Isernia la Pineta (with isotopic data from Lisiecki and Raymo, 2005). The "In-situ, MIS 11, MIS 9, MIS 7 and MIS 5" ages are the weighted means (W 1/4 1/s2) ESR/U-series dates calculated using the present-day dosimetry value and the simulated gamma-dose rates for the different MIS respectively. The ESR/U-series ages are given with 1 sigma error bars while ${ }^{40} \mathrm{Ar} /{ }^{39} \mathrm{Ar}$ age is given with 2 sigma bars (Coltorti et al., 2005) (after Shao et al., 2011).

Figure 6: U-series analyses of a tooth from Venta Micena site (VM0502), performed by LAICP-MS at the University of Melbourne (after Duval et al., 2011).

(A) Position of the three laser ablation tracks (labelled 1 to 3 ) carried out on the longitudinal section of VM0502.

(B) ${ }^{234} \mathrm{U} /{ }^{238} \mathrm{U}$ and ${ }^{230} \mathrm{Th} /{ }^{234} \mathrm{U}$ ratios along the three transversal profiles. Red solid lines represent the values obtained by alpha spectrometry on the same tissues. Keys: $d=d e n t i n e, ~ e=e n a m e l, c=c e m e n t$. Domains close to the cement-enamel junction and dentine-enamel junction (in grey) show clearly more constant U-series data values and these were used for age calculation. Numerical mean values are also shown. Standard errors correspond to $1 \mathrm{~s}$. Average ratios of the grey areas of the three laser tracks are: ${ }^{234} \mathrm{U} /{ }^{238} \mathrm{U}=1.47 \pm 0.01$ and ${ }^{230} \mathrm{Th} /{ }^{234} \mathrm{U}=1.02 \pm 0.03$ for dentine; ${ }^{234} \mathrm{U} /{ }^{238} \mathrm{U}=1.44 \pm 0.03$ and ${ }^{230} \mathrm{Th} /{ }^{234} \mathrm{U}=1.05 \pm 0.05$ for cement.

Table 1: List of publications versus sample types, countries. Detailed references may be found in Supplementary information. 


\section{References}

Apers, D., Debuyst, R., Canniere, P. de, Dejehet, F., Lombard, E., 1981. A criticism of the dating by electronic paramagnetic resonance (ESR) of the stalagmite floors of the Caune de l'Arago at Tautavel. In Absolute Dating and lsotope Analyses in Prehistory:Methods and Limits (Edited by Lumley H. de and Labeyrie J.), 533-550. CNRS, Paris.

Arnold, L.J., Demuro, M., Pares, J.M., Perez-Gonzalez, A., Arsuaga, J.L., Bermúdez de Castro, J.M., Carbonell, E., 2015. Evaluating the suitability of extended-range luminescence dating techniques over Early and Middle Pleistocene timescales: published datasets and case studies from Atapuerca, Spain Quaternary International, 389, 167-190.

Arnold, L.J., Demuro, M., Spooner, N.A., Prideaux, G.J., McDowell, M.C., Camens, A.B., Reed, E.H., Pares, J.M., Arsuaga, J.L., Bermúdez de Castro, J.M., Carbonell, E., 2019. Single-grain TT-OSL bleaching characteristics: Insights from modern analogues and OSL dating comparisons. Quaternary Geochronology, 49, 45-51.

Bahain, J.J., Yokoyama, Y., Falguères C., Sarcia, M.N., 1992. ESR dating of tooth enamel: a comparison with K-Ar dating. Quaternary Science reviews, 11, 245-250.

Bahain J.J., Yokoyama Y., Falguères C., Bibron R., 1994. Choix du signal à utiliser lors de la datation par résonance paramagnétique électronique (RPE) de calcites stalagmitiques quaternaires. C. R. Acad. Sci. Paris, $318,375-379$.

Bahain, J.J., Yokoyama, Y., Masaoudi, H., Falguères C., Laurent, M., 1994. Thermal behaviour of ESR signals observed in various natural carbonates. Quaternary Geochronology (Quaternary Science Reviews), 13, 671674.

Bahain J.J., Falguères C., Laurent M., Dolo J.M., Shao Q., Auguste P., Tuffreau A., 2015. ESR/U-series dating of faunal remains from the palaeoanthropological site of Biach-Saint-VAast (Pas-de-Calais, France). Quaternary Geochronology, 30, 541-546.

Barabas, M., Bach, A., Mudelsee, M., Mangini, A., 1992a. General properties of the paramagnetic centre at $\mathrm{g}=2.0006$ in carbonates. Quaternary Science Reviews, 11, 165-171.

Barabas, M., Bach, A., Mudelsee, M., Mangini, A., 1992b. Dose response and thermal behaviour of the ESR signal at $\mathrm{g}=2.0006$ in carbonates. Quaternary Science Reviews, 11, 173-179.

Ben Arous E., Falguères C., Tombret O., El Hajraoui M.A., Nespoulet R., 2019. Combiend US-ESR dating of fossil teeth from EL Harhoura 2 cave (Morocco) : New data about the end of the MSA in Temara region. Quaternary International, in press.

Berger, G.W., Pérez-Gonzalez A., Carbonell, E., Arsuaga, J.L., Bermudez de Castro, J.M., Ku, T.L., 2008. Luminescence chroinology of cave sediments at the Atapuerca paleoanthropological site, Spain. Journal of Human Evolution, 55, 300-311.

Coltorti, M., Cremaschi, M., Delitala, M.C., Esu, D., Fornascri, M., McPherron, A., Nicoletti, M., van Otterloo, R., Peretto, C., Sala, B., Sehmidt, V. and Sevink, J., 1982. Reversed magnetic polarity at an early Lower Palaeolithic site in central Italy. Nature, 300, 173-176. 
Coltorti, M., Féraud, G., Marzoli, A., Peretto, C., Ton-That, T., Voinchet, P., Bahain, J.J., Minelli, A., Thun Hohenstein, U., 2005. New Ar/39Ar, stratigraphic and palaeoclimatic data on the Isernia la Pineta Lower Palaeolithic site, Molise, Italy. Quaternary International 131, 11-22.

Debuyst, R., Dejehet, F., Idrissi, S., 1993. Paramagnetic centers in -y-irradiated synthetic monohydrocalcite. Applied Radiation and Isotopes, 44, 293-297.

Despriée J., Moncel M.H., Arzarello M., Courcimault G., Voinche P., Bahain J.J., Falguères C., 2018. The 1-million-year-old quartz assemblage from Pont-de-Lavaud (Centre, France) in the European context. Journal of Quaternary Science, 33, 639-661.

Duval M., Falguères C., Bahain J.J., Grün R., Shao Q., Aubert M., Hellstrom J., Dolo J.M., Agusti J., MartinezNavarro B., Palmquist P., Toro-Moyano I., 2011. The challenge of dating Early Pleistocene fossil teeth by the combined uranium-series-electron spin resonance method: the Venta Micena palaeontological site (Orce, Spain). Journal of Quaternary Science, 26, 603-615.

Duval M., Falguères C., Bahain J.J., 2012. Chronology of the oldest hominid settlements in Western Europe: contribution of the combined US-ESR dating method applied to fossil teeth from Early Pleistocene Spanish localities. Quaternary Geochronology, 10, 412-417.

Duval M., Bahain J.J., Falguères C., Garcia J., Guilarte V., Grün R., Martinez K., Moreno D., Shao Q., Voinchet P., 2014. Revisiting the ESR chronology of the Early Pleistocene hominin occupation at Vallparadis (Barcelona, Spain). Quaternary International, 389, 213-223.

Duval, M., Guilarte, V., 2014. ESR dosimetry of optically bleached quartz grains extracted from PlioQuaternary sediment : Evaluating some key aspects of the ESR signals associated to the Ti-centers. Radiation Measurements, 78, 28-41.

Edwards, R.L., Chen, J.H., Wasserburg, G.J., 1987. U-238-U-234-Th-230-Th-232 systematics and the precise measurement of time over the past 500,000 years. Earth Planet and Sci. Letters, 81, 175-192.

Falguères, C., Yokoyama, Y., Miallier, D., 1991. Stability of some centres in quartz. Nucl. Tracks Radiat. Meas., 18, 155-161.

Falguères, C., Miallier, D., Sanzelle, S., Faïn J., Laurent M., Montret M., Pilleyre T., Bahain J.J., 1994. Potential use of the E' center as an indicator of initial resetting in TL/ESR dating of volcanic materials. Quaternary geochronology (Quaternary Science Review), 13, 619-623.

Falguères, C., Bahain, J.J., Yokoyama, Y., Arsuaga, J.L., Bermudez de Castro, J.M., Carbonell, E., Bischoff, J.L., Dolo, J.M., 1999. Earliest humans in Europe: the age of TD6 Gran Dolina, Atapuerca, Spain. Journal of Human Evolution, 37, 343-352

Falguères, C., Yokoyama, Y., Shen, G.J., Bischoff, J.L., Ku, T.-L., Lumley, H. de, 2004. New U-series dates at the Caune de l'Arago, France. Journal of Archaeological Science, 31, 941-952. 
Falguères, C., Bahain, J.J., Dolo, J.M., Mercier, N., Valladas, H., 2007. On the interest and the limits of using combined ESR/U-series model in the case of very late uranium uptake. Quaternary Geochronology, 2, 403-408.

Falguères, C., Bahain, J.J., Duval, M., Shao, Q., Han, F., Lebon, M., Mercier, N., Perez-Gonzalez, A., Dolo, J.M., Garcia, T., 2010. A 300-600 ka ESR/U-series chronology of Acheulian sites in Western Europe. Quaternary International, 223-224, 293-298.

Falguères C., Shao, Q., Han, F., Bahain, J.J., Richard, M., Perrenoud, C., Moigne, A.M., Lumley H. de, 2015. New ESR and U-series dating at Caune de l'Arago, France: a key-site for European Middle Pleistocene. Quaternary Geochronology, 30, 547-553.

Feigl, F.J., Fowler, W.B., Yip, K.L., 1974. Oxygen vacancy model for the E'1 Center in SiO2. Solid State Commun., 14, 225-229.

Griscom, D. L., 1978. Defects and impurities in alpha-quartz and fused silica. In "The physics of SiO2 and its interfaces (Edited by Pantelides, S T), 232-252 Proc lnt Topical Conf, Yorktown, New York.

Grün, R., 1989. Electron spin resonance (ESR) dating. Quaternary International, 1, 65-109.

Grün, R., 2009. The DATA program for the calculation of ESR age estimates on tooth enamel. Quaternary Geochronology, 4, 231-232.

Grün, R., Invernati, C., 1985. Uranium accumulation in teeth and its effect on ESR dating -A detailed study of a mammoth tooth. Nuclear Tracks and Radiation Measurements 10: 869-878.

Grün, R., Katzenberger-Apel, O., 1994. An alpha irradiator for ESR dating. Ancient TL 12, 35-38.

Grün, R., Schwarcz, H.P., 1987. Some remarks on "ESR dating of bones”. Ancient TL, 5(2), 1-9.

Grün, R., Schwarcz, H.P., Chadam, J.M., 1988. ESR dating of tooth enamel : coupled correction for U-uptake and U-series disequilibrium. Nuclear Tracks and Radiation Measurements, 14, 237-241.

Hennig, G.J., Grün, R., 1983. ESR dating in Quaternary geology. Quaternary Science Reviews, 2, 157-238.

Higham, T., Douka, K., Wood, R., Bronk Ramsey, C., Brock, F., Basell, L., Camps, M., Arrizabalaga, A., Baena, J., Barroso-Ruiz, C., Bergman, C., Boitard, C., Boscato, P., Caparros, M., Conard, N.J., Draily, C., Froment, A., Galvan, B., Gambassini, P., Garcia-Moreno, A., Grimaldi, S., Haesaerts, P., Holt, B., IriarteChiapusso, M.-J., Jelinek, A., Jorda Pardo, J.F., Maillo-Fernandez, J.-M., Marom, A., Maroto, J., Menendez, M., Metz, L., Morin, E., Moroni, A., Negrino, F., Panagopoulou, E., Peresani, M., Pirson, S., de la Rasilla, M., Riel-Salvatore, J., Ronchitelli, A., Santamaria, D., Semal, P., Slimak, L., Soler, J., Soler, N., Villaluenga, A., Pinhasi, R., Jacobi, R., 2014. The timing and spatiotemporal patterning of Neanderthal disappearance. Nature, 512, 306-309.

Ikeya, M., 1975. Dating a stalactite by electron paramagnetic resonance. Nature, 255, 48-50. 
Ikeya, M., 1978. Electron Spin Resonance as a method of dating. Archaeometry, 20, 147-158.

Ikeya, M., 1981. Dating methods and limitation by electron spin resonance (ESR). In Absolute Dating and Isotope Analyses in Prehistory--Methods and Limits (Edited by Lumley H. de and Labeyrie J.), 437-455. CNRS, Paris.

Ikeya, M., 1993. New applications of Electron Spin Resonance: Dating, dosimetry and microscopy. World Scientific, Singapore.

Ingicco, T., van den Bergh, G. D., Jago-on, C., Bahain, J.-J., Chacón, M. G., Amano, N., Forestier, H., King, C., Manalo, K., Nomade, S., Pereira, A., Reyes, M. C., Sémah, A.-M., Shao, Q., Voinchet, Q., Falguères, C., Albers, P. C. H., Lising, M., Lyras, G., Yurnaldi, D., Rochette, P., Bautista, A., de Vos, J., 2018. Earliest known hominin activity in the Philippines by 709 thousand years ago. Nature, 557, 233-237.

Lisiecki, L.E., Raymo, M.E., 2005. A Pliocene-Pleistocene stack of 57 globally distributed benthic d O records. Paleoceanography 20, PA1003.

Lumley H. de, Labeyrie, J., 1981. Absolute dating and Isotope Analysis in Prehistory Methods and limits, Prétirage, 720 pp, CNRS, Paris.

Lumley H. de, 1967. Découverte d'habitat de l'Acheuléen ancien dans des d6p6ts mind,liens, sur le site de Terra Amata. C. R. Acad. Sci. Paris 264, série D, 801-804.

Lumley H. de and Lumley M. A. de,1971. Découverte de restes humains anténéanderthaliens datés du début du Riss à la Caune de l'Arago (Tautavel, Pyrénées- Orientales). C. R. Acad. Sci. Paris 272, série D, 1739-1742.

Mackey, J.H. Jr, Boss, J.W., Wood, D.E., 1970. EPR study of substitutional aluminium related hole centers in synthetic alpha-quartz. Journal of Magnetic Resonance, 3, 44-54.

McMorris, D.W., 1969. Trapped-electron dating : ESR studies. Nature, 222, 870-871

McMorris, D. W., 1970. ESR detection of fossil alpha damage in quartz. Nature, 226, 146 148.

McMorris, D.W., 1971. Impurity color centers in quartz and trapped electron dating : electron spin resonance, thermoluminescence studies. Journal of Geophysical Research, 76, 78757887.

Marfunin, A.S., 1979. Spectroscopy, luminescence and Radiation centers in minerals. Springer-Verlag, Berlin Heidelberg New York.

Miallier, D., Sanzelle, S., Falguères, C., Faïn, J., Montret, M., Pilleyre, T., Soumana, S., Laurent, M., Camus, G., De Goër de Herve A., 1994. Intercomparisons of red TL and ESR signals from heated quartz grains. Radiation Measurements, 23, 143-153.

Moncel, M.H., Despriée, J., Voinchet, P., Tissoux, H., Moreno, D., Bahain, J.J., Courcimault, G., Falguères, C., 2013. Early evidence of Acheulean settlement in Northwestern Europe - La Noira Site, a 700000 year-old occupation in the Center of France. PLOSone, 8, e75529. 
Moreno, D., Falguères, C., Pérez-González, A., Duval, M., Voinchet, P., Benito-Calvo, A., Ortega, A.I., Bahain, J.-J., Sala, R., Carbonell, E., Bermúdez de Castro, J.M. and Arsuaga, J.L., 2012. ESR chronology of alluvial deposits in the Arlanzón valley (Atapuerca, Spain): Contemporaneity with Atapuerca Gran Dolina site. Quaternary Geochronology 10, 418-423

Moreno D., Falguères C., Perez-Gonzalez A., Voinchet P., Ghaleb B., Despriée J., Bahain J.J., Sala R., Carbonell E., Bermudez de Castro J.M., Arsuaga J.L., 2015. New radiometric dates on the lowest section (TD1 to TD6) of Gran Dolina site (Atapuerca, Spain). Quaternary Geochronology, 30, 535-540.

Odom, A.L., Rink, W.J., 1989. The natural accumulation of Schotty-Frenkel defects: Implications for a quartz geochronometer. Geology, 17, 55-58.

Parés, J.M., Pérez-Gonzalez, A., 1995. Palaeomagnetic age for Hominid fossils at Atapuerca archaeological site, Spain. Science 269, 830-832.

Pereira, A., Nomade, S., Falguères, C., Bahain, J.J., Tombret, O., Garcia, T., Voinchet, P., Bulgarelli, G.M., Anzidei, A.P., 2017. New 40Ar/39Ar and ESR/U-series data for La Polledrara di Cecanibbio archaeological site (Lazio, Italy). Journal of Archaeological Science: Reports 1, 20-29.

Peretto, C., Arnaud, J., Moggi-Cecchi, J., Manzi, G., Nomade, S., Pereira, A., Falguères, C., Bahain, J.J., Grimaud-Hervé, D., Berto, C., Sala, B., Lembo, G., Muttillo, B., Gallotti, G., Thun Hohenstein, U., Vaccaro, C., Coltorti, M., Arzarello, M., 2015. A human deciduous tooth and new 40Ar/39Ar dating results from the Middle Pleistocene archaeological site of Isernia La Pineta, southern Italy. PLoS One, 10 (10), e0140091.

Poole, C.P., Farach, H., Bishop, T.P., 1978. Electron Spin Resonance of minerals. Magnetic Resonance Review, 4, 225-289.

Potter, E.-K., Stirling, C.H., Andersen M.B., Halliday A.N., 2005. High precision Faraday collector MCICPMS thorium isotope ratio determination. Int. Journal of Mass Spectrometry, 247, 10-17.

Pozzi J.P., Rousseau L., Falguères C., Mahieux G., Deschamps P., Shao Q., Kachi D., Bahain J.J., Tozzi C., 2019. U-Th dated speleothem recorded geomagnetic excursions in the Lower Brunhes. Scientific Reports, 9:1114, 1-8.

Quaegebeur, J.P., Yokoyama, Y., 1981. Electron Spin Resonance (ESR) study of quartz grains of the Caune de l'Arago at Tautavel. in: H. de Lumley, J. Labeyrie (Eds.), Absolute Dating and Isotope Analysis in PrehistoryMethods and Limits, Prétirage, CNRS, Paris, 1981, 557-564.

Richard M., Falguères C., Pons-Branchu E., Bahain J.J., Voinchet P., Lebon M., Valladas H., Dolo J.M., Puaud S., Rué M., Daujeard C., Moncel M.H., Raynal J.P., 2015. Contribution of ESR/U-series dating method to Late Middle Palaeolithic sites chronology of Middle Rhône valley, Southeastern France. Quaternary Geochronology, $30,529-534$

Rink, W.J., 1997. Electron spin resonance (ESR) dating and ESR applications in Quaternary science and archaeometry. Radiation Measurements, 27, 5-6, 975-1025.

Sahnouni, M., Pares, J.M., Duval, M., Caceres, I., Harichane, Z., Made van der, J., Perez-Gonzalez, A., Abdessadok, S., Kandi, N., Derradji, A., Medig, M., Boulagghraif, K., Semaw, S. 2018. 1.9-million-and 2.4million-year-old artifacts and stone tool-cutmarked bones from Ain Boucherit, Akgeria. Science, 362, 12971301. 
Shao, Q., Bahain, J.J., Falguères, C., Peretto, C., Arzarello, M., Minelli, A., Thun Hohenstein, U., Dolo, J.M., Garcia, T., Frank, N., Douville, E., 2011. New ESR/Useries data for the early Middle Pleistocene site of Isernia la Pineta, Italy. Radiat. Meas. 46, 847-852.

Skinner, A.F., 1983. Overestimate of stalagmitic calcite ESR dates due to Laboratory heating. Nature, 304, 152154.

Smith, B.W., Smart, P.L., Symons, M.C.R., 1985. ESR signals in a variety of speleothem calcites and their suitability for dating. Nuclear Tracks and Radiation Measurements, 10, 837-844.

Tissoux H., Falguères C., Voinchet P., Toyoda S., Bahain J.J., Despriée J., 2007. Potential use of Ti-center in ESR dating of fluvial sediment. Quaternary Geochronology, 2, 367-372.

Tissoux H., Toyoda S., Falguères C., Voinchet P., Masashi T., Bahain J.J., Despriée J., 2008. ESR dating of sedimentary quartz from two Pleistocene deposits using $\mathrm{Al}$ and Ti centers. Geochronometria, 30, 23-31.

Toro-Moyano, I., Martínez-Navarro, B., Agustí, J., Souday, C., Bermúdez de Castro, J.M., Martinón-Torres, M., Fajardo, B., Duval, M., Falguères, C., Oms, O., Parés, J.M., Anadón, P., Julià, R., García-Aguilar, J.M., Moigne, A.-M., Espigares, M.P., Ros-Montoya, S. and Palmqvist, P., 2013. The oldest human fossil in Europe, from Orce (Spain). Journal of Human Evolution 65, 1-9.

Toyoda, S., Ikeya, M., 1991. Thermal stabilities of paramagnetic defect and impurity centers in quartz: basis for ESR dating of thermal history. Geochem. Journal, 25, 437-445.

Toyoda, S., 1992. Production and decay characteristics of paramagnetic defects in quartz : application to ESR dating. Ph. D. Thesis, Osaka University, Osaka, Japon, 106 p., unpublished.

Toyoda S., Voinchet P., Falguères C., Dolo J.M., Laurent M., 2000. Bleaching of ESR signals by the sunlight : a laboratory experiment for establishing the ESR dating of sediments. Applied Radiation and Isotopes, 52, $1357-1362$.

Toyoda S., Falguères C., 2003. The method to represent the ESR signal intensity of the aluminium hole center in quartz for the purpose of dating. Advances in ESR applications, 20, 7-10.

Voinchet, P., Falguères, C., Laurent, M., Toyoda, S., Bahain, J.J., Dolo, J.M., 2003. Artificial optical bleaching of the aluminium center in quartz. Implications to ESR dating of sediments. Quaternary Geochronology (Quaternary Science Reviews), 22, 1335-1338.

Voinchet, P., Falguères, C., Tissoux, H., Bahain, J.J., Despriée, J., Pirouelle, F., 2007. ESR dating of fluvial quartz : Estimate of the minimal distance transport required for getting a maximal optical bleaching. Quaternary Geochronology, 2, 363-366

Voinchet, P., Despriée, J., Tissoux, H., Falguères, C., Bahain, J.-J., Gageonnet, R., Dépont, J., Dolo, J.-M., 2010. ESR chronology of alluvial deposits and first human settlements of the Middle Loire Basin (Region Centre, France), Quaternary Geochronology, 5, 381-384.

Voinchet, P., Moreno, D., Bahain, J.J., Falguères, C., Tissoux, H., Tombret, O., Moncel, M.H., Schreve, D., Candy, I., Antoine, P., Ashton, N., Beamish, M., Cliquet, D., Despriée, J., Lewis, S., Limondin-Lozouet, N., Locht, J.L., Parfitt, S., Pope, M., 2015. New chronological data (ESR and ESR/U-series) for the earliest Acheulean sites of Northwestern Europe. Journal of Quaternary Science, 30, 610-622. 
Voinchet P., Yin G., Falguères C., Liu C., Han F., Sun X., Bahain J.J., 2019. Dating of stepped quaternary fluvial terrace system of the Yellow River by Electron Spin Resonance, Quaternary Geochronology, 49, 278282.

Walther, R., Barabas, M., Mangini, A., 1992. Basic ESR studies on recent corals. Quaternary Science Reviews, 11, 191-196.

Weil, J.A., 1984. A review of electron Spin Spectroscopy and its applications to the study of paramagnetic defects in crystalline quartz. Phys. Chem. Minerals, 10, 149-165.

Yokoyama, Y., Nguyen, H.V., 1980. Direct and non destructive dating of marine sediments, manganese nodules and corals by high resolution gamma-ray spectrometry. In Isotope marine chemistry, E.D. Goldberg et al. (Eds), Uchida Rokakuho, Tokyo, 259-289.

Yokoyama, Y., Nguyen, H.V., 1981a. Datation directe de l'Homme de Tautavel par la spectrométrie gamma, non destructive, du crâne humain fossile Arago XXI, Comptes Rendus Académie des Sciences de Paris 292, 741-744.

Yokoyama, Y., Nguyen, H.V., 1981b. Datation directe par la spectrométrie gamma non destructive du crâne humain fossile AragoXXI, des ossements fossiles d'animaux et des stalagmites de la caune de l'Arago à Tautavel, in: H. de Lumley, J. Labeyrie (Eds.), Absolute Dating and Isotope Analysis in Prehistory—Methods and Limits, Prétirage, CNRS, Paris, 1981a, 355-375.

Yokoyama, Y., Quaegebeur, J.P., Bibron, R., Léger, C., Nguyen, H.V., Poupeau, G., 1981a. Electron spin resonance (ESR) dating of bones of the caune de l'Arago at Tautavel, in: H. de Lumley, J. Labeyrie (Eds.), Absolute Dating and Isotope Analysis in Prehistory—Methods and Limits, Prétirage, CNRS, Paris, 457-492.

Yokoyama, Y., Quaegebeur, J.P., Bibron, R., Léger, C., Nguyen, H.V., Poupeau, G., 1981b. Electron spin resonance (ESR) dating of stalagmites of the caune de l'Arago at Tautavel, in: H. de Lumley, J. Labeyrie (Eds.), Absolute Dating and Isotope Analysis in Prehistory- Methods and Limits, Prétirage, CNRS, Paris, 507-532.

Yokoyama, Y., Quaegebeur, J.P., Bibron, R., Léger, C., Nguyen, H.V., Poupeau, G., 1982.Datation du site de l'Homme de Tautavel par la résonance de spin électronique (ESR), Comptes Rendus Académie des Sciences de Paris, 294, 759-764.

Yokoyama, Y., Quaegebeur, J.P., Bibron, R., Léger, C., 1983. ESR Dating of palaeolithic calcite: thermal annealing experiment and trapped electron life time. PACT 9, 371-379.

Yokoyama, Y., Falguères, C., Quaegebeur, J.P., 1985. ESR dating of quartz from quaternary sediments: first attempt, Nuclear Tracks, 10, 921-928.

Yokoyama, Y., Falguères, C., Quaegebeur, J.P. 1986. ESR dating of sediment baked by lava-flows: comparison of palaeodoses for $\mathrm{Al}$ and Ti centers. In : ESR dating and dosimetry, Ionics, Tokyo, 197-204.

Zimmerman, D.W., 1971. Thermoluminescent Dating using fine grains from pottery. Archaeometry, 13, 29-52. 


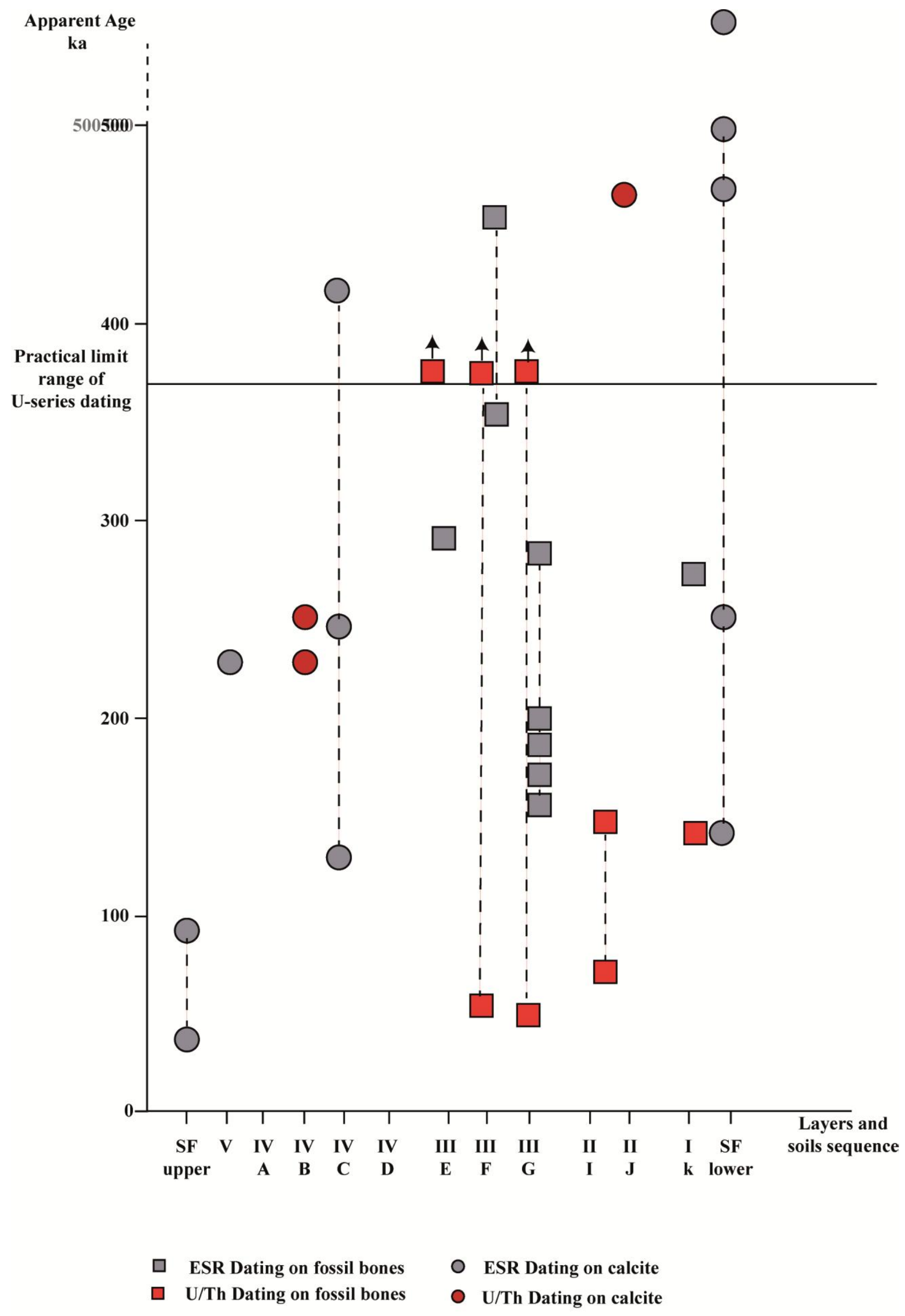


A)

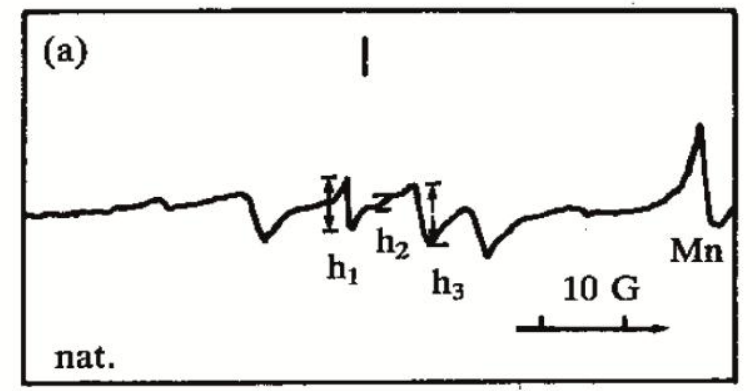

(c)

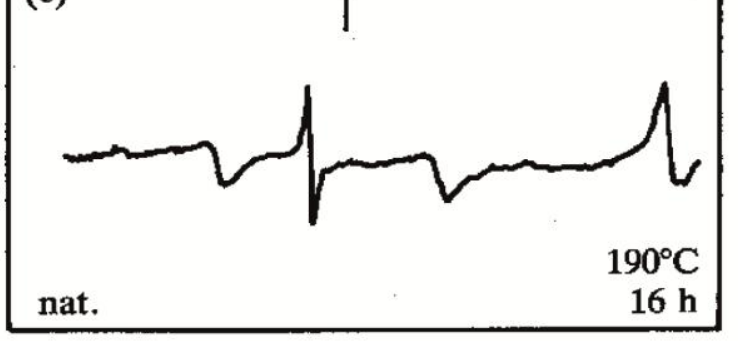

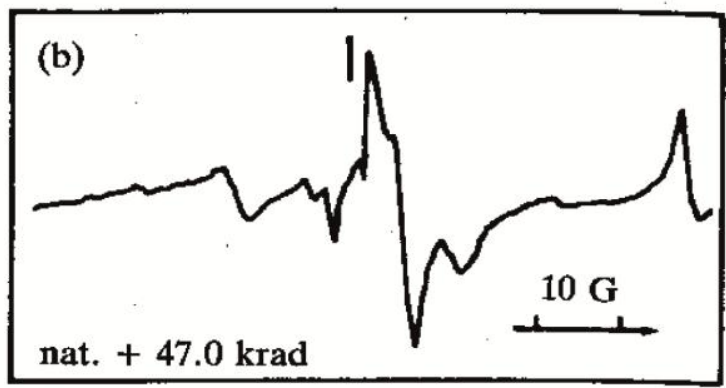

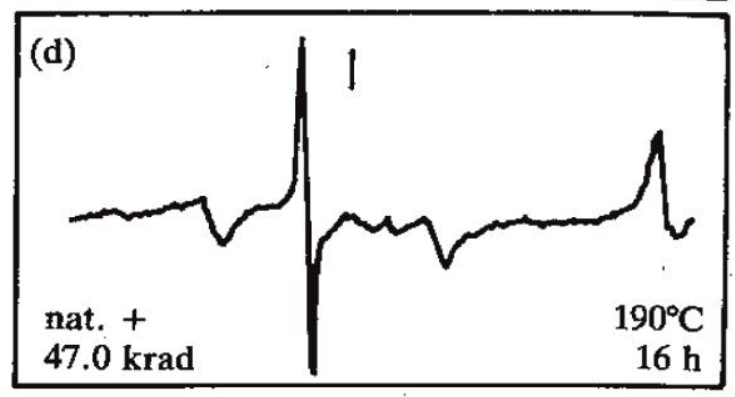

B)

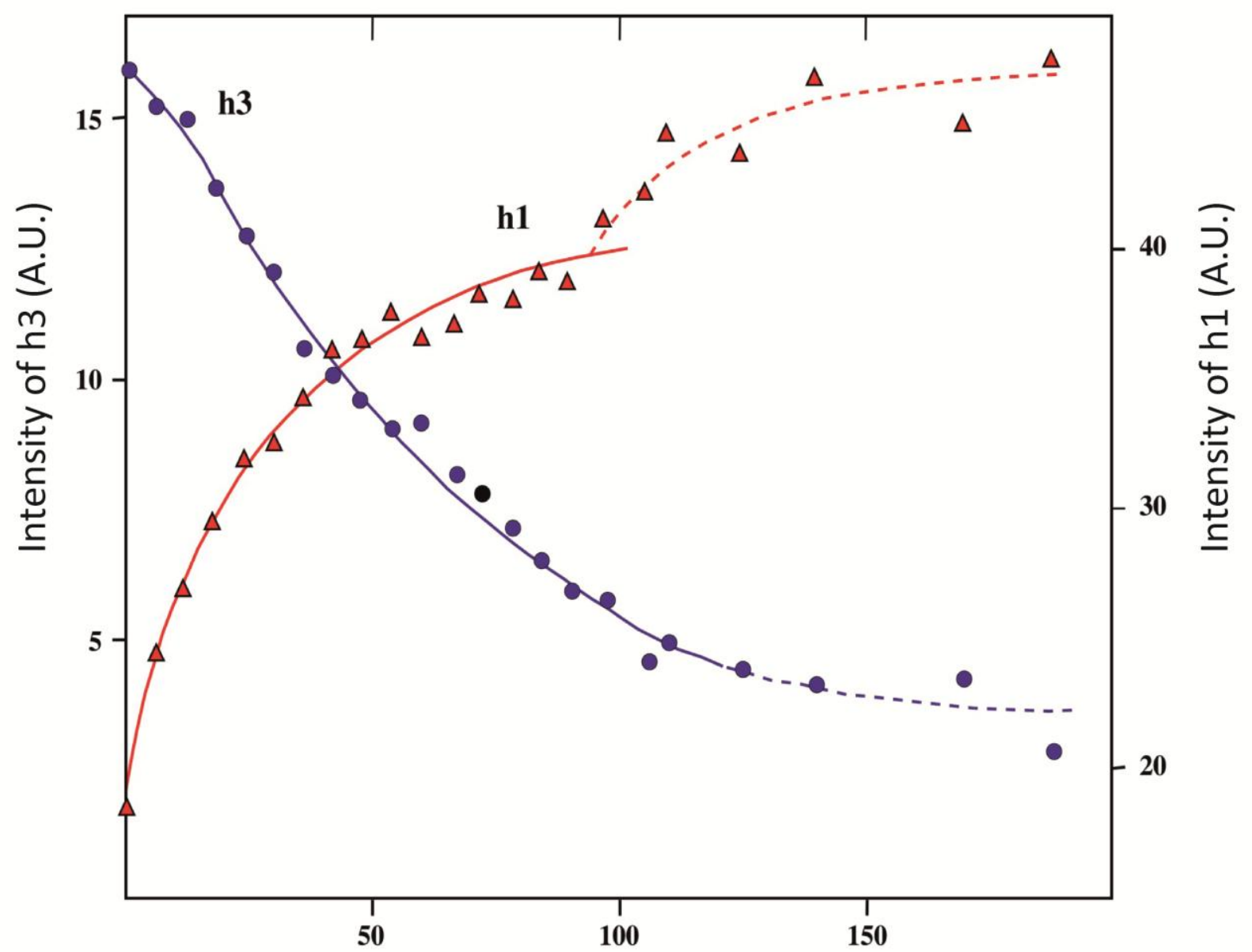

Annealing Time at $200.5^{\circ} \mathrm{C}(\mathrm{min})$ 


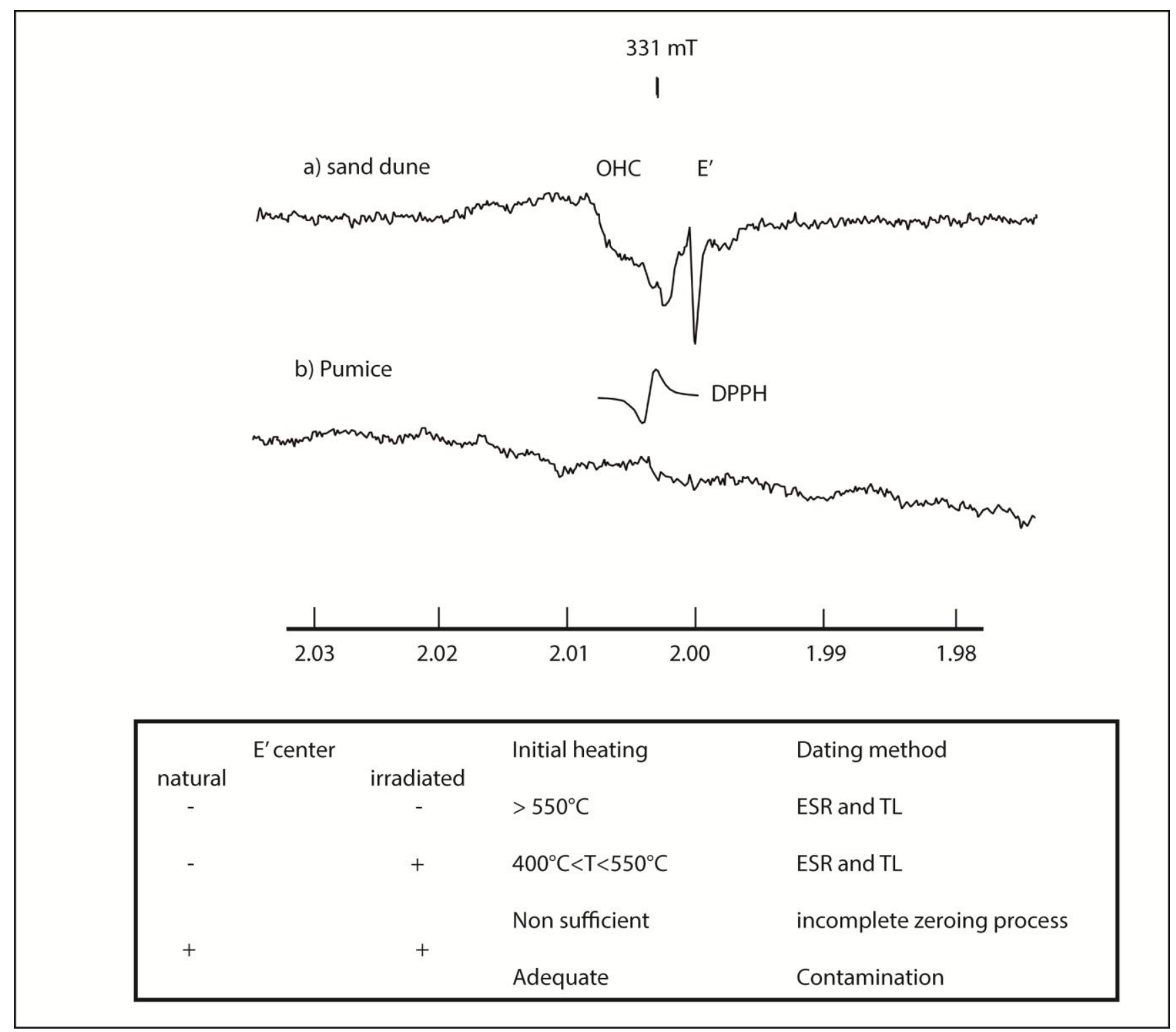




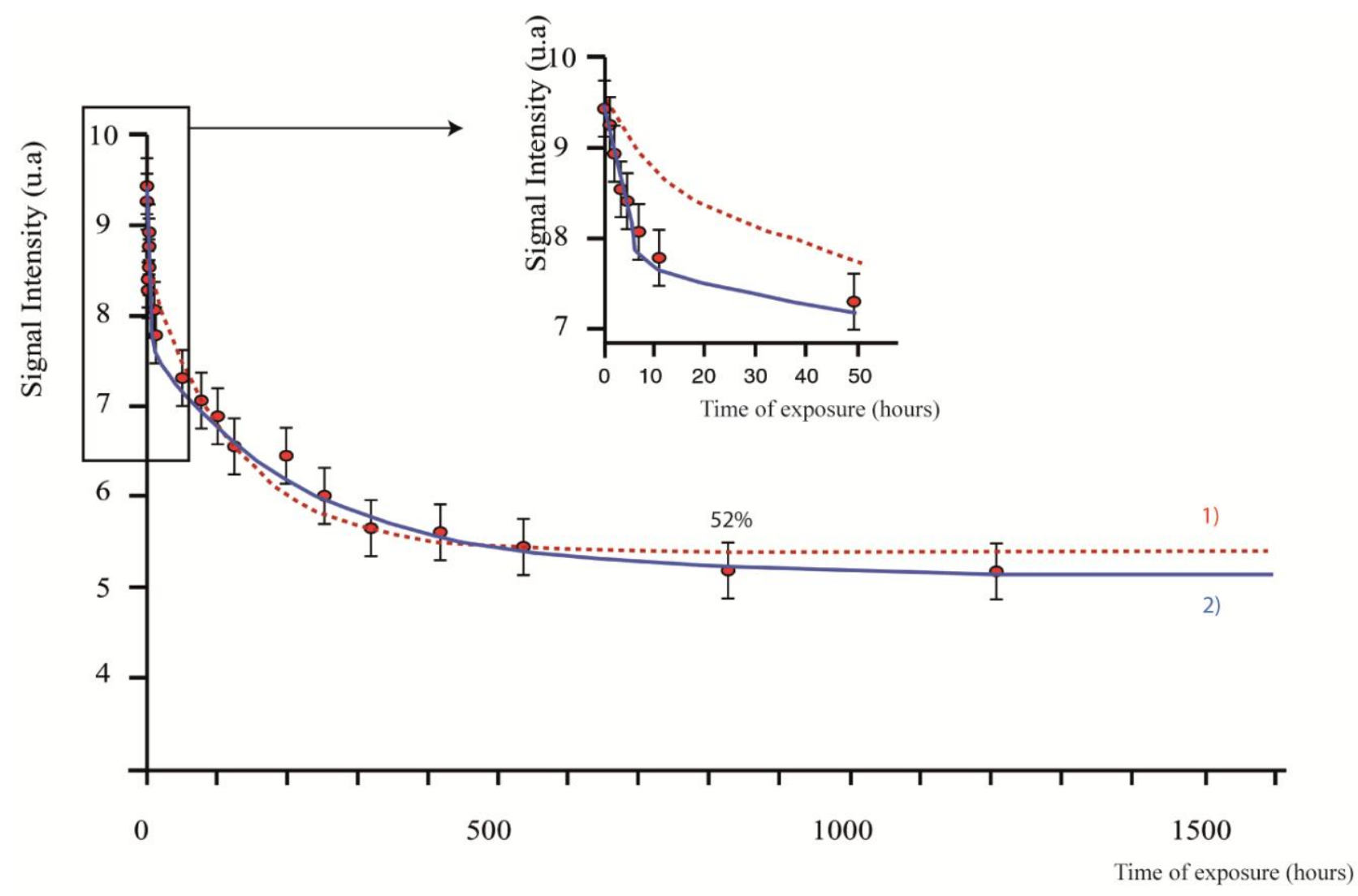




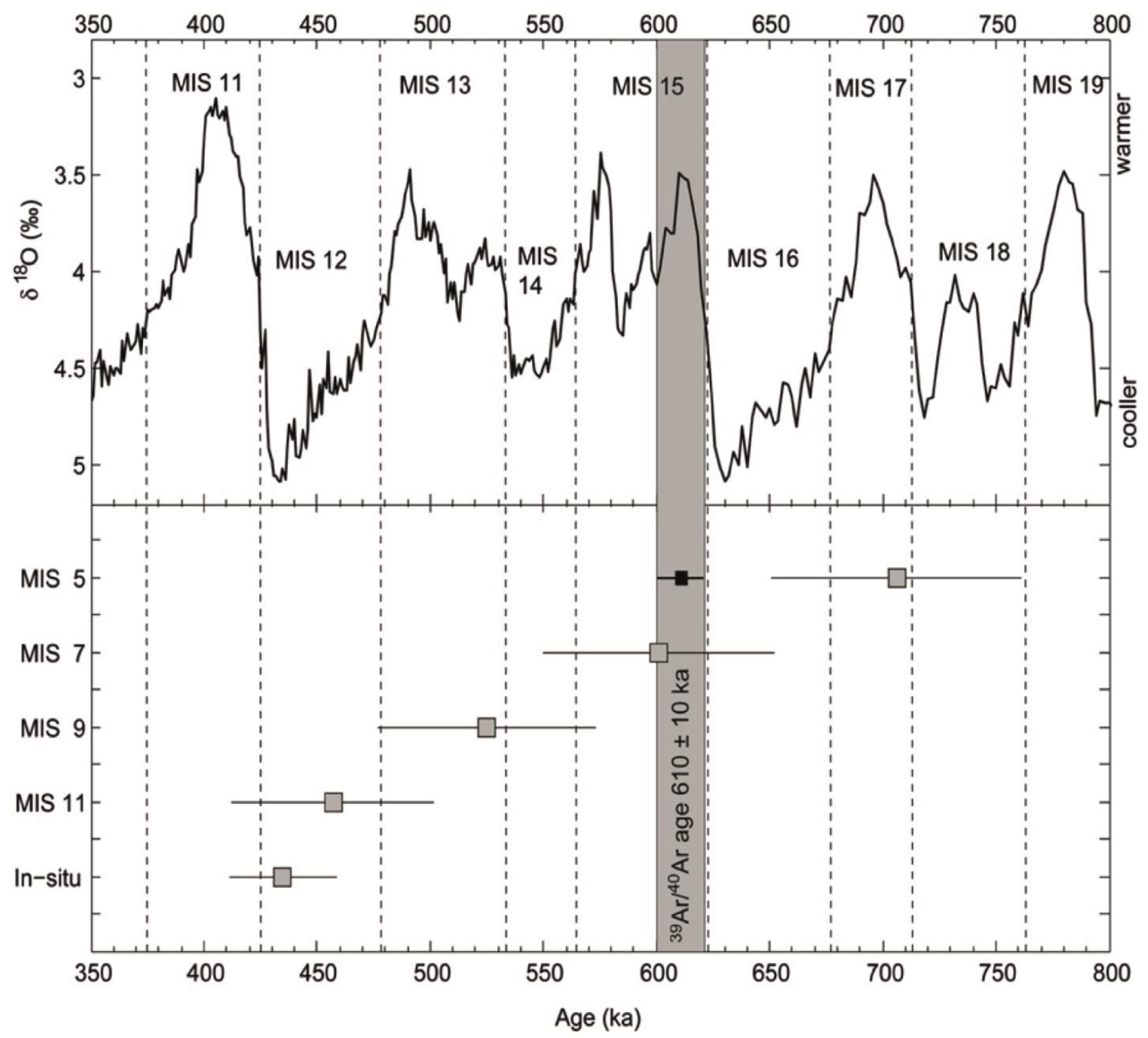




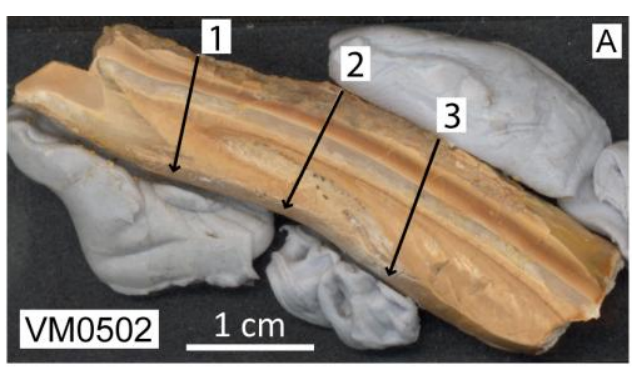

Area selected for combined US-ESR age calculation

Isotopic ratio obtained by alpha spectrometry

B
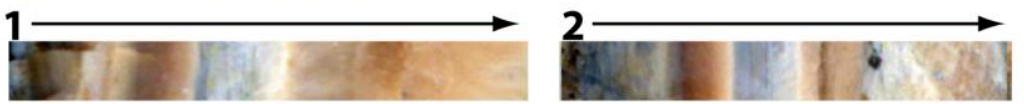
$5 \mathrm{~mm}$
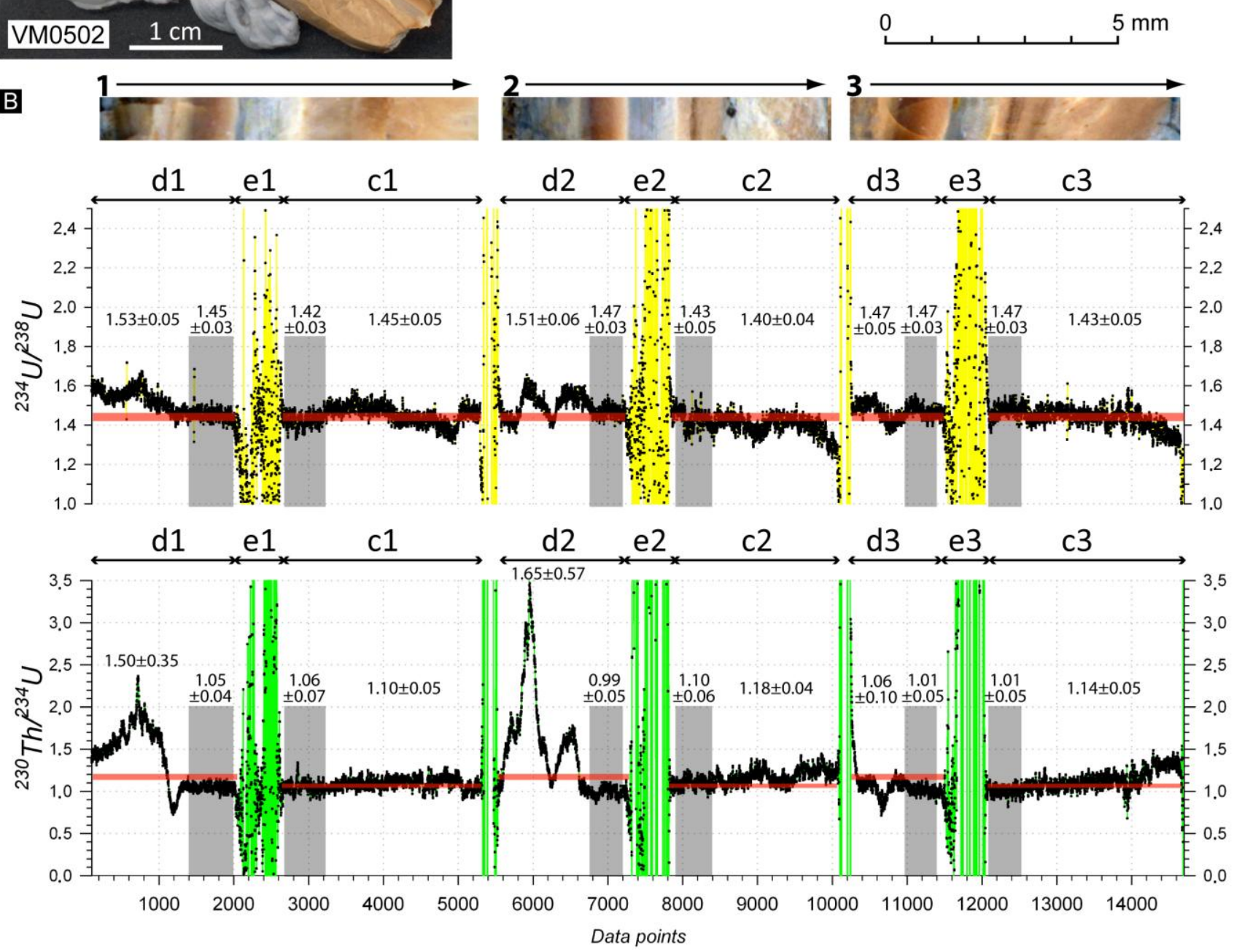


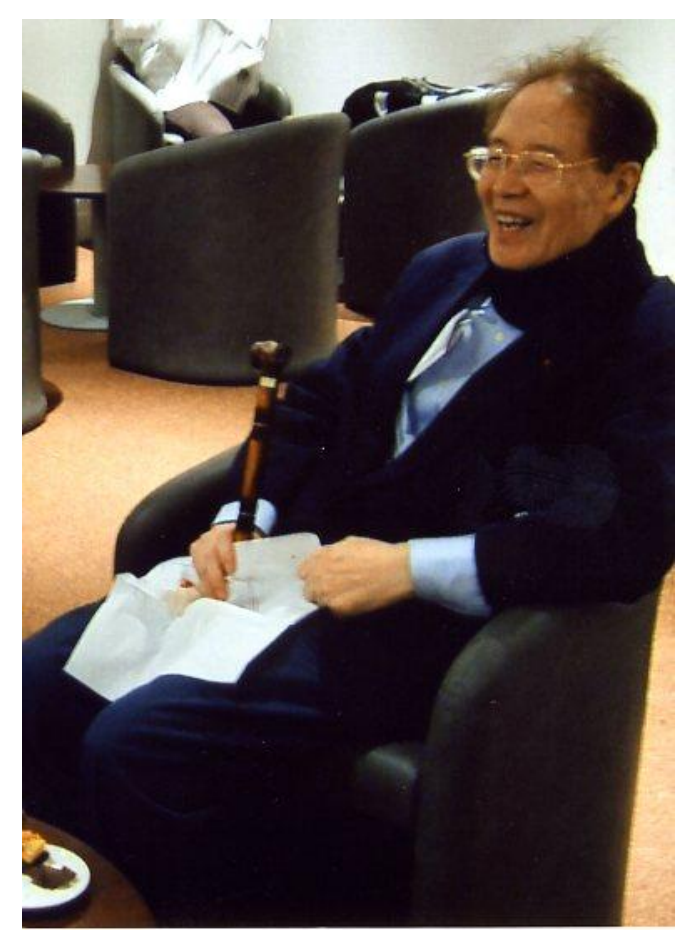

